\title{
Change of biochemical parameters in cows with abomasal displacement after omentopexy
}

\author{
Ramūnas Antanaitis, \\ Robertas Stoškus, \\ Mindaugas Televičius \\ Department of Non-Infectious \\ Diseases of the Veterinary Academy \\ of the Lithuanian University \\ of Health Sciences, \\ Tilžès St. 18, \\ LT-47181 Kaunas \\ E-mail: antanaitis@lva.lt
}

The aim of the research is to evaluate the postsurgical health condition of cows with left abomasal displacement (LDA) based on the blood serum biochemical indices. The research has been performed at a Lithuanian cattle farm having 600 dairy cows in 2007-2014. The research included in total 30 cows diagnosed with LDA during the clinical trial. For the purpose of control, 25 clinically healthy cows were selected based on the analogy principle. All the cows with LDA have undergone surgical treatment according to omentopexia. For the ketosis prevention, cows were given $0.300 \mathrm{~kg}$ of monopropylenglycol for 14 days after surgical correction. For the purpose of biochemical testing, blood samples were collected from $v$. coccigea right before the surgery (Day 0), and subsequently seven days (Day 7), fourteen days (Day 14), and twenty-one days (Day 21) after the surgery. Blood serum was tested for the following parameters: calcium $(\mathrm{Ca})$, phosphorus $(\mathrm{P})$, magnesium (Mg), aspartataminotranspherase (AST), albumines (Alb), beta-hydroxybutyrates (BHB), glucose concentration. Cows with LDA were observed to develop ketosis and hepatic lesions after surgical correction. Cows with LDA demonstrated reliably $(\mathrm{p}<0.001)$ higher BHB concentration than clinically healthy cows (average BHB of cows with LDA amounted to $1.16 \mathrm{mmol} / \mathrm{l}$, whereas that of healthy cows was $0.8 \mathrm{mmol} / \mathrm{l}$ ). The average AST concentration in cows with LDA amounted to 158 (IU/l), whereas that in control cows was $86.9 \mathrm{IU} / \mathrm{l}(\mathrm{p}<0.001)$. The average blood glucose level in cows with LDA amounted to $2.27 \mathrm{mmol} / \mathrm{l}$, whereas that in control cows was $2.62 \mathrm{mmol} / \mathrm{l}(\mathrm{p}<0.05)$. Hypocalcemia is characteristic of cows with LDA. The average calcium concentration in the blood serum of cows with LDA amounted to $2.09 \mathrm{mmol} / \mathrm{l}$, whereas that of healthy cows was $2.73 \mathrm{mmol} / \mathrm{l}(\mathrm{p}<0.05)$. Calcium concentration remained low for the entire period of the trial (until Day 21 after the surgical correction). Risks of ketosis and hepatic lesions decreased after 21 days following the treatment (when BHB AST levels decreased and blood glucose level increased).

Key words: cows, LDA, surgical treatment, biochemical testing

\section{INTRODUCTION}

Abomasal displacement in cattle is a worldwide disease, the majority of which is seen with higher frequency specifically after calving (Radostits et al., 2007). Higher incidence rate of LDA was observed in cows during their second to fourth lactation. The LDA incidence was very high in cows fed with a ration enriched in concentrates $(>60 \%)$ compared to the incidence in animals fed with at least $50 \%$ forage. The body temperature, heart rate, and respiratory rates were increased in LDA-affected cows (Mokhber et al., 2013).

The left displacement of the abomasum (LDA) is a common disease in periparturient dairy cows (Zurr, Leonhard-Marek, 2012). Plasma $\beta$-hydroxybutyrate (BHB) levels above the reference range are regarded as risk factors for the occurrence of LDA (Zurr, Leonhard-Marek, 2012). Cows with displacement of the abomasum (LDA) are at increased risk of complicated ketosis and metritis (Radostits et al., 2007). Displacement of abomasums has been introduced 
as one of the most important metabolic and organic internal disorders of cattle. Abomasal displacement occurs most frequently in high-yielding cows during early lactation (Veysi et al., 2003).

Cattle with LDA showed reduction in appetite, selective appetite (eagerness to eat hay but reluctance to eat grains), pasty feces, characteristic highpitched ping in percussion over the left middle to upper third of the abdomen between ribs 9 and 11, and a splashing sound with bell-like echo induced by ballottement (Mokhber et al., 2013).

Surgical correction of the left displaced abomasum (LDA) is common in lactating dairy cattle (Nathalie et al., 2013). The left abomasal displacement (LDA) is seen more frequently than the right displacement (Doll et al., 2009).

Development of the abomasal displacement is highly influenced by calcium deficiency: all sick cows showed increased enzyme AST activity. It was found that prophylaxis of high producing dairy cows in a herd against abomasal displacement may be comprised of regular evaluations of blood serum biochemical indices, milk testing data analysis and quantitative as well as qualitative analysis of the diets (Antanaitis et al., 2007).

\section{MATERIALS AND METHODS}

The research has been performed at a Lithuanian cattle farm having 600 dairy cows in 2007-2014. The research included in total 30 cows diagnosed with LDA during the clinical trial. For the purpose of control, 25 clinically healthy cows were selected based on the analogy principle.

All the cows with LDA have undergone surgical treatment according to omentopexia. For ketosis prevention, cows were given $0.300 \mathrm{~kg}$ of monopropylenglycol for 14 days after surgical correction (Herdt, 2000). For the purpose of biochemical testing, blood samples were collected from $v$. coccigea right before the surgery (Day 0 ), and subsequently seven days (Day 7), fourteen days (Day 14), and twenty-one days (Day 21) after the surgery. Blood serum was tested for the following parameters: calcium $(\mathrm{Ca})$, phosphorus $(\mathrm{P})$, magnesium $(\mathrm{Mg})$, aspartataminotranspherase (AST), albumines (Alb), hydroxybutyrates (BHB), glucose (Glu). The blood serum was measured by a computerized analyzer Hitachi 705 (Hitachi, Japan) using DiaSys (Diagnostic Systems GmbH, Germany).
The test data were processed using the SPSS statistical package (SPSS for Windows 15.0, SPSS Inc., Chicago, IL, USA, 2006). The data were considered reliable from the statistic point of view when $\mathrm{p}<0.05$.

Scientific research was carried out in accordance with the Law of the Republic of Lithuania on Animal Care, Housing, and Use No. VIII-500 (Valstybès žinios No. 108, 28.11.1997) as well as substatutory acts - Order of State Veterinary Service Regarding Veterinary Requirements on Laboratory Animal Breeding, Care, and Reproduction (No. 4-361, 31.12.1998) and Regarding Use of Laboratory Animals for Scientific Experiments (No. 4-16, 18.01.1999). The new edition of the Law came into force on 01.01.2013, subparagraph 10 of Article 8 came into force on 01.07.2013, and subparagraph 2 of Article 7 and subparagraph 4 of Article 2 come into force on 01.01. 2016.

The aim of the research is to evaluate changes of some blood biochemical parameters in cows with LDA after omentopexy.

\section{RESULTS AND DISCUSSION}

Hydroxybutyrates. Cows with LDA demonstrated reliably $(\mathrm{p}<0.001)$ higher BHB concentration than clinically healthy cows (average BHB of cows with LDA amounted to $1.16( \pm 0.23) \mathrm{mmol} / \mathrm{l}$, whereas that of healthy cows was $0.8( \pm 0.1) \mathrm{mmol} / \mathrm{l})$ (Fig. 1). After the LDA treatment, gradual reduction in BHB was observed, whereas BHB of cows in the control group started increasing on Day 14 and reached the same level as that of cows with LDA on Day 21. BHB indicates the completeness of oxidization ("burning") of fat in the liver. Ketone bodies (BHB, acetone and acetoacetate) are intermediate

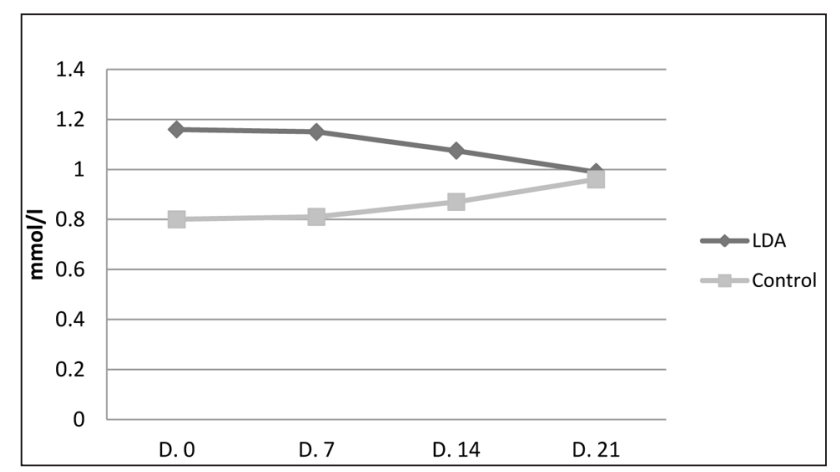

Fig. 1. BHB variation in the blood serum of cows with LDA and the control group 
metabolites of oxidation of fatty acids; as the supply of NEFA to the liver exceeds the ability of liver to completely oxidize the fatty acids to supply energy, the amount of ketone body production increases. Ketone bodies can be used by muscle as an alternative fuel source to glucose, sparing glucose for milk production (Herdt, 2000).

For the cows with LDA, the average AST concentration during surgery was found to amount to $158( \pm 5.3) \mathrm{IU} / \mathrm{l}$, whereas that for healthy cows was $86.9( \pm 8.2) \mathrm{IU} / \mathrm{l}(\mathrm{p}<0.001)$. After the surgical correction, the AST concentration was observed to gradually decrease, while on Day 21 it reached almost the same level as that of control cows (cows with LDA - 84( \pm 13$)$ IU/l, control - 87.1( \pm 7.0$)$ IU/l) (Fig. 2). Serum biochemical changes in cows with LAD revealed a significant increase in ALP and AST. These results were agreeable with those of O'Zkan and Poulsen (1986), Zadnik (2003), and ElAttar et al. (2007). Metabolic imbalances in dairy cows have a strong impact on liver function and vice versa. In line with this, increased levels of AST activity and ALP were also significantly associated with failure (Voros, Karsai, 1987; Lenz, 1993) that could be attributed to hepatic lipidosis, endotoxemia, and hepatocyte damage as well (Zadnik, 2003; El-Attar et al., 2007). Aspartate aminotransferase (AST) is an enzyme that becomes elevated with cell damage and may be elevated in cows with fatty liver disease. Although there have been associations between AST and subsequent occurrence of displaced abomasums (Geishauser et al., 1998), the test lacks both sensitivity and specificity. For assessing the adaptive response to energy balance NEFA and BHBA are the best two measures. Subclinical ketosis (BHBA > $1200-1400 \mu \mathrm{mol} / \mathrm{L}$ ) in early lactation

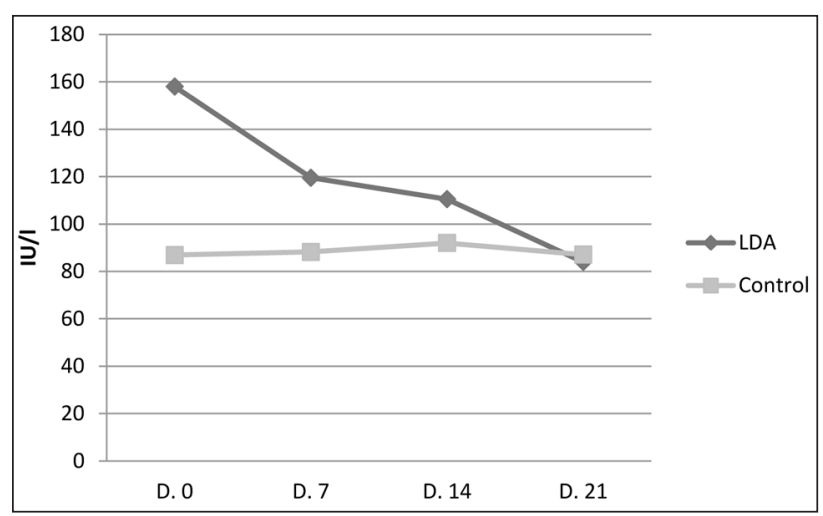

Fig. 2. AST level variation in the blood serum of cows with LDA and the control group is associated with 3 to 8 times increased risk of LDA (Geishauser et al., 2000; Duffield et al., 2009).

The trial showed the average calcium concentration in the blood serum of cows with LDA of $2.09( \pm 0.17) \mathrm{mmol} / \mathrm{l}$, whereas that of healthy cows was $2.73( \pm 0.14) \mathrm{mmol} / \mathrm{l}(\mathrm{p}<0.05)$. The statistically reliable difference between the two groups persisted throughout the entire period of the trial $(\mathrm{p}<0.05)$ (Fig. 3). The present results demonstrated a significant reduction in calcium in cows with LDA (Veysi et al., 2003; Zadnik, 2003; Delgado-Lecaroz et al., 2000; El-Attar et al., 2007), but there were no significant differences in phosphorous and magnesium concentrations of cows with abomasal displacement compared to healthy cows. The puerperal hypocalcemia represents a significant risk factor for development of abomasum displacement in cows (Houe et al., 2001). In the cows that developed clinical LDA, decreased values of calcium were detected prior to LDA (Geishauser et al., 2000). Calcium demand is tremendous immediately postpartum and monitoring serum calcium in cows less than a week following calving may have some utility, but before or beyond this time period it makes no sense to measure calcium. Recently, low serum calcium concentrations (subclinical hypocalcemia) have been linked with increased risk of early lactation culling (Duffield et al., 2005).

The blood glucose level in cows with LDA amounted to $2.27( \pm 0.35) \mathrm{mmol} / \mathrm{l}$, whereas in control cows it was $2.62( \pm 0.17) \mathrm{mmol} / \mathrm{l}(\mathrm{p}<0.05)$. On Day 7 , the blood glucose level in cows with LDA was observed to increase to $2.65( \pm 0.11) \mathrm{mmol} / \mathrm{l}$ and reached the blood glucose level of cows in the control group, whereas on Day 14 exceeded it (cows with LDA - 2.89 $( \pm 0.39) \mathrm{mmol} / \mathrm{l}$,

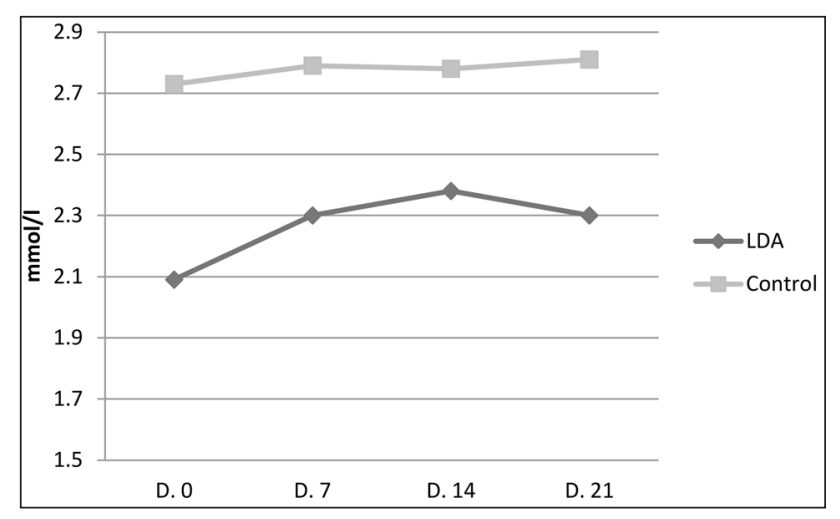

Fig. 3. Calcium level variation in the blood serum of cows with LDA and the control group 
control - 2.62( \pm 0.17$) \mathrm{mmol} / \mathrm{l})$. Statistically reliable difference $(\mathrm{p}<0.05)$ also remained on Day 21 (cows with LDA - 2.99 $( \pm 0.18) \mathrm{mmol} / \mathrm{l}$, control - 2.67( \pm 0.17$) \mathrm{mmol} / \mathrm{l})$ (Fig. 4). Significant increase in the blood glucose level in cows with displaced abomasums is a result that conforms to that of Zadnik (2003) and El-Attar et al. (2007). Holtenius et al. (1998; 2000) reported decreased abomasal motility in cows with high insulin combined with high glucose levels (Holtenius et al., 1998; 2000). On the other hand, Van Winden et al. (2003) found low levels of insulin and glucose in cows that developed abomasum displacement after

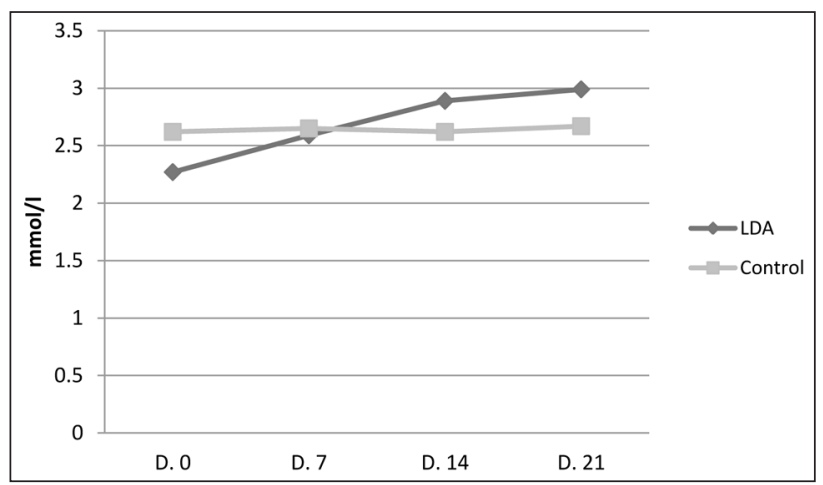

Fig. 4. The blood glucose level variation in the blood serum of cows with LDA and the control group

10 days. The exact mechanism by which the abomasal displacement leads to hyperglycemia is unknown (Van Winden et al., 2002). Glucose is the primary metabolic fuel and is absolutely required for vital organ function, fetal growth, and milk production. In dairy cows, the massive energy demand to support milk production is partly met through gluconeogenesis. Glucose concentrations are under tight homeostatic control. Therefore, although glucose has a central role in metabolism, it is a poor analyte for monitoring or investigating herd problems (Herdt, 2000).

No other statistical reliabilities between other recorded parameters were found.

\section{CONCLUSIONS}

Cows with LDA subject to surgical treatment according to Dirksen and given $0.300 \mathrm{~kg}$ of monopropylenglycol for 14 days after the surgical correction showed the following:
1. Cows with LDA were observed to develop ketosis and hepatic lesions after surgical correction. Cows with LDA demonstrated reliably $(\mathrm{p}<0.001)$ higher BHB concentration than clinically healthy cows (average BHB of cows with LDA amounted to $1.16 \mathrm{mmol} / \mathrm{l}$, whereas that of healthy cows was $0.8 \mathrm{mmol} / \mathrm{l})$. The average AST concentration in cows with LDA amounted to 158 (IU/l), whereas that in control cows was $86.9 \mathrm{IU} / \mathrm{l}(\mathrm{p}<0.001)$. The average blood glucose level in cows with LDA amounted to $2.27 \mathrm{mmol} / \mathrm{l}$, whereas that in control cows was $2.62 \mathrm{mmol} / \mathrm{l}(\mathrm{p}<0.05)$.

2. Hypocalcemia is characteristic for cows with LDA. The average calcium concentration in the blood serum of cows with LDA amounted to $2.09 \mathrm{mmol} / \mathrm{l}$, whereas that of healthy cows was $2.73 \mathrm{mmol} / \mathrm{l}(\mathrm{p}<0.05)$. The calcium concentration remained low for the entire period of the trial (until Day 21 after the surgical correction).

3. Risks of ketosis and hepatic lesions decreased after 21 days following the treatment (when BHB AST levels decreased and blood glucose level increased).

Received 27 June 2014 Accepted 10 December 2014

\section{REFERENCES}

1. Antanaitis R., Kučinskienė J., Kučinskas A. 2007. Šliužo dislokacijos etiologijos ir prevencijos analizé pieninių veislių Lietuvos karvių bandoje. Veterinarija ir zootechnika. T. 38(60). P. 3-8.

2. Delgado-Lecaroz R., Warnick L. D., Guard C. L., Smith M. C., Barry D. A. 2000. Cross-sectional study of the association of abomasal displacement or volvulus with serum electrolyte and mineral concentrations in dairy cows. The Canadian Veterinary Journal. Vol. 41(4). P. 301-305.

3. Doll K., Sickinger M., Seeger T. 2009. New aspects in the pathogenesis of abomasal displacement. The Veterinary Journal. Vol. 181. P. 90-96.

4. Duffield T. F., Lissemore K. D., McBride B. W., Leslie K. E. 2009. Impact of hyperketonemia in early lactation dairy cows on health and production. Journal of Dairy Science. Vol. 92. P. 571-580.

5. El-Attar H. M., Yassein M., Abd El-Raof Y. M., Ghanem M. M. 2007. Alterations in the clinical, hematological and biochemical pictures in abomasal displacement in cows in Egypt. Journal of Veterinary Medicine. P. 102-109.

6. Geishauser T., Shoukri M., Kelton D., Leslie K. 1998. Analysis of survivorship after displaced abomasum is diagnosed in dairy cows. Journal of Dairy Science. Vol. 81. P. 2346-2353. 
7. Geishauser T., Leslie K., Duffield T. 2000. Prevention and prediction of displaced abomasum in dairy cows. Bovine Practice. Vol. 34. P. 51-55.

8. Herdt T. H. 2000. Ruminant adaptation to negative energy balance. Influences on the etiology of ketosis and fatty liver. Veterinary Clinics of North America: Food Animal Practice. Vol. 16. P. 215-230.

9. Holtenius K., Jacobsson S. O., Holtenius P. 1998. Effects of intravenous infusion of glucose and pancreatic glucagon on abomasal function in dairy cows. Acta Veterinaria Scandinavica. Vol. 39. P. 291-300.

10. Holtenius K., Sternbauer K., Holtenius P. 2000. The effect of the plasma glucose level on the abomasal function in dairy cows. Journal of Animal Science. Vol. 78. P. 1930-1935.

11. Houe H., Stergaard S., Thilsing-Hansen T., Jorgensen R. J., Larsen T., Jorgensen T., Agger J. F., Blom J. Y. 2001. Milk fever and subclinical hypocalcaemia. Acta Veterinaria Scandinavica. Vol. 42. P. 1-29.

12. Lenz U. 1993. Untersuchungen zum Gerinnungsstatus und zur Bedetung der Gerinnungsinhibitoren Antithrombin III uns protein $C$ in der Diagnostik der Hepatosteatose von Kuhen mit linksseitiger Labmagenverlagerung. Hannover. Tieraztol. Hochsch., Diss. P. 15-20.

13. Mokhber Dezfouli M., Eftekhari Z., Sadeghian S., Bahounar A., Jeloudari M. 2013. Evaluation of hematological and biochemical profiles in dairy cows with left displacement of the abomasum. Comparative Clinical Pathology. Vol. 22. P. 175-179.

14. Newby N. C., Pearl D. L., LeBlanc S. J., Leslie K. E., von Keyserlingk M. A., Duffield T. F. 2013. The effect of administering ketoprofen on the physiology and behavior of dairy cows following surgery to correct a left displaced abomasum. Journal of Dairy Science. Vol. 96. P. 1511-1520.

15. O'Zkan K., Poulsen J. S. D. 1986. Changes in ionized calcium content and related clinical chemical parameters in cases of left sided abomasal displacement. Nordisk Veterinaer Medicin. Vol. 38. P. 277-287.

16. Radostits O. M., Gay C. C., Hinchcliff K. W., Constable P. D. 2007. Diseases of the abomasum. In: Veterinary Medicine - A Textbook of the Diseases of Cattle, Horses, Sheep, Pigs and Goats. 10th edn. Philadelphia: Elsevier Health Sciences. P. 353-374.

17. Van Winden S. C. L., Jorritsma R., Müller K. E., Noordhuizen J. P. T. M. 2003. Feed intake, milk yield, and metabolic parameters prior to left displaced abomasums in dairy cows. Journal of Dairy Science. Vol. 86. P. 1465-1471.

18. Van Winden S. C. L., Muller K. E., Kuiper R., Noordhuizen J. P. T. M. 2002. Studies on the pH value of abomasal contents in dairy cows during the first three weeks after calving. Journal of Veterinary Medicine Series A. Vol. 49. P. 157-160.

19. Veysi A., Mahmut O. K., Murat B., Ismail S., Fatih M. B., Fahrettin A. 2003. The Study on the
Relationship of Abomasal Displacement and Fatty Liver Syndrome in Dairy Cows. Abstracts - Poster Presentations at 11 th ICPD.

20. Voros K. L., Karsai F. 1987. Blut-und pasensaftveraderungen cordem Auftreten der linksseitigen Lambagenverlagerung bei Milchkuhen. Tierarztl Umsch. Vol. 42. P. 617-624.

21. Zadnik T. 2003. A comparative study of the hematobiochemical parameters between clinically healthy cows and cows with displacement of the abomasum. Acta Veterinaria (Beograd). Vol. 53(5-6). P. 297-309.

22. Zurr L., Leonhard-Marek S. 2012. Effects of $\beta$-hydroxybutyrate and different calcium and potassium concentrations on the membrane potential and motility of abomasal smooth muscle cells in cattle. Journal of Dairy Science. Vol. 95. P. 5750-5759.

Ramūnas Antanaitis, Robertas Stoškus, Mindaugas Televičius

\section{KARVIŲ, SERGANČIŲ ŠLIUŽO DISLOKACIJA, BIOCHEMINIŲ RODIKLIŲ KAITA PO OMENTOPEKSIJOS}

\section{Santrauka}

Tyrimo tikslas - po gydymo omentopeksijos būdu ịvertinti šliužo dislokaciją i kairę pusę (ŠDK) sirgusių karvių kraujo biocheminių rodiklių kaitą. Tyrimas atliktas 2007-2014 m. Lietuvos gyvulininkystès ūkyje, laikančiame 600 melžiamų karvių. Tirta 30 karvių, kurioms buvo diagnozuota ŠDK. Kontrolei (analogu principu) buvo atrinktos 25 kliniškai sveikos karvès. Visoms karvèms, sirgusioms ŠDK, omentopeksijos būdu atliktas operacinis gydymas. Ketozės prevencijai po operacijos 14 dienų karvès buvo girdomos monopropilenglikoliu (po $0,300 \mathrm{~kg}$ ). Kraujas biocheminiam tyrimui buvo imamas iš $v$. coccigea prieš pat operaciją $(0 \mathrm{~d}$.), praejjus septynioms paroms $(7 \mathrm{~d}$.), keturiolikai parų (14 d.) ir dvidešimt vienai parai (21 d.). Iš kraujo serumo nustatyta: kalcio $(\mathrm{Ca})$, fosforo $(\mathrm{P})$, magnio $(\mathrm{Mg})$, aspartataminotransferazės (AST), albuminų (Alb), betahidroksibutiratų (BHB), gliukozės koncentracijos. Karvèms, susirgusioms ŠDK, po operacijos stebima ketozè ir kepenų pažeidimai. ŠDK BHB koncentracija buvo statistiškai patikimai $(\mathrm{p}<0,001) \mathrm{di}$ desnè, nei kliniškai sveikų karvių (vidutinė BHB ŠDK sirgusių karvių - 1,16 mmol/l, sveikų - 0,8 mmol/l). Vidutinė fermento AST koncentracija ŠDK sirgusių karvių - 158 (IU/l), kontrolinių - 86,9 IU/l ( $\mathrm{p}<0,001)$; sirgusių ŠDK vidutinė gliukozès koncentracija - 2,27 mmol/l, kontrolinès grupès - 2,62 mmol/l $(\mathrm{p}<0,05)$. Karvėms, susirgusioms ŠDK, būdinga hipokalcemija. Sirgusių ŠDK karvių vidutinė kalcio koncentracija kraujo serume - 2,09 mmol/l, sveikų - 2,73 mmol/l (p < 0,05). Žema kalcio koncentracija išsilaike ir viso tyrimo metu (iki $21 \mathrm{~d}$. po operacijos). Ketozès ir kepenų pažeidimų rizika sumažèjo praèjus 21 parai po gydymo (sumažèja BHB ir AST koncentracijos, padideja gliukozès koncentracija kraujo serume).

Raktažodžiai: karvés, ŠDK, operacija, biocheminiai tyrimai 